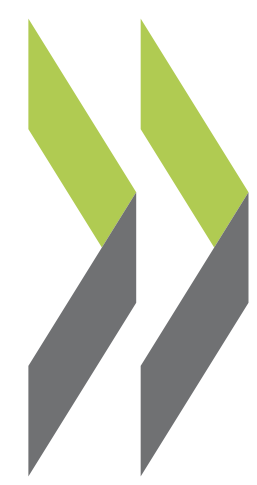

OECD Economics Department Working Papers No. 125

Global Effects

of the European Carbon Tax
Giuseppe Nicoletti,

\author{
Joaquim Oliveira Martins
}




\section{ECONOMICS DEPARTMENT}

\section{WORKING PAPERS}

No. 125

\section{GLOBAL EFFECTS OF THE EUROPEAN CARBON TAX}

by

Giuseppe Nicoletti and Joaquim Oliveira-Martins

Resource Allocation Division

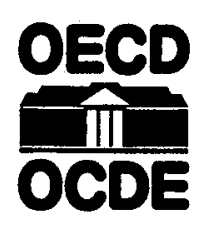



GENERAL DISTRIBUTION

OCDE/GD (92) 187

ECONOMICS DEPARTMENTT

WORKING PAPERS

No. 125

GLOBAL EFFECTS OF THE EUROPEAN CARBON TAX

BY

GIUSEPPE NICOLETTI AND JOAQUIM OLIVEIRA-MARTINS

RESOURCE ALLOCATION DIVISION

ORGANISATION FOR ECONOUIC CO-OPERATION AND DEVELOPMENTI Paris 1992

002809

COMPLETE DOCUMANT AVAILABLE ON OLIS IN ITS ORIGINAL FORMAT 


\section{GLOBAL EFFECTS OF THE EUROPEAN CARBON TAX}

The aim of this paper is to analyse the implications of the European Commission proposal of a mixed energy cum carbon tax to curb $\mathrm{CO}_{2}$ emissions from a global perspective. The paper deals with the effects of this proposal on emissions and welfare in both the EC and the rest of the world by concentrating on three main issues: i) the effectiveness of the proposed tax measures in terms of curbing EC and global $\mathrm{CO}_{2}$ emissions; ii) the implied costs for the EC and the other countries/regions of the world; and iii) the implications of the EC proposal for the world distribution of emissions and the competitiveness of the EC economy. In this connection, the relevance of the so-called "carbon leakages" - i.e. the displacement of polluting activities from countries participating in an emission reduction agreement to countries not concerned by the agreement - is examined. The paper provides quantitative answers to these issues using simulations with GREEN, the global dynamic applied general equilibrium (AGE) model developed by the OECD Secretariat in order to study the costs of policies aimed at reducing $\mathrm{CO}_{2}$ emissions.

L'objet de cette étude est d'analyser d'une point de vue global les effets de la proposition de la Commission Européenne d'une taxe mixte sur l'énergie et le contenu en carbone, pour réduire les émissions de $\mathrm{CO}_{2}$. Les effets de cette proposition sur les émissions et le bien-être collectif de la CEE et du reste du monde sont abordés selon trois perspectives : i) l'impact des mesures fiscales proposées sur les émissions globales et celles de la CEE ; ii) les couts induits pour la CEE et les autres pays/régions du monde ; et iii) les effets de cette proposition de la Commission sur la répartition des émissions dans le monde et sur la compétitivité de l'économie européenne. A ce titre, la pertinence des prétendues "fuites de carbone" -- i.e. le déplacement des activités polluants de pays signataires d'un accord de réduction des émissions vers des pays non concernés par cet accord, est examinée. Cette étude propose des réponses quantifiées à ces questions au moyen de simulations effectuées avec GREEN, le modèle global dynamique d'équilibre genéral appliqué (EGA) mis au point par le Secrétariat de l'OCDE pour évaluer les coûts des politiques visant à réduire les émissions de $\mathrm{CO}_{2}$.

Copyright OECD, 1992 


\section{Contents}

I. INTRODUCTION $\ldots \ldots \ldots \ldots \ldots \ldots \ldots \ldots \ldots \ldots \ldots \ldots \ldots \ldots \ldots \ldots$

II. OVERVIEW OF THE GREEN MODEL $\ldots \ldots \ldots \ldots \ldots \ldots \ldots \ldots \ldots \ldots \ldots$

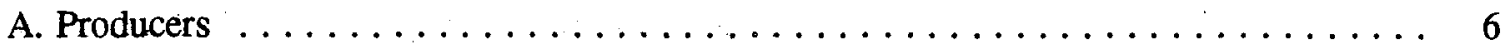

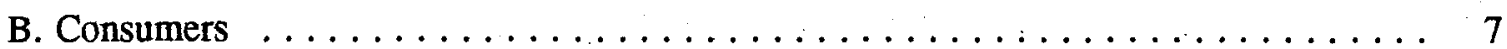

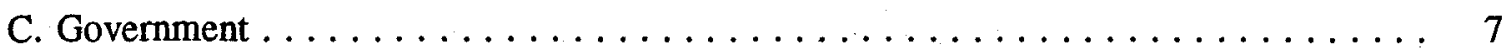

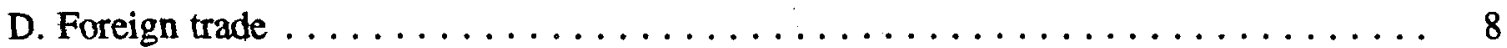
E. Closure $\ldots \ldots \ldots \ldots \ldots \ldots \ldots \ldots \ldots \ldots \ldots \ldots \ldots \ldots \ldots \ldots$

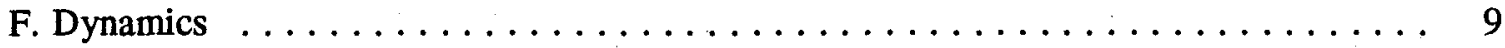

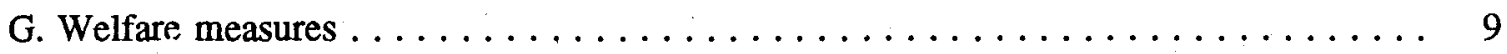

III. SIMULATING THE COMMISSION'S PROPOSAL $\ldots \ldots \ldots \ldots \ldots \ldots \ldots \ldots \ldots \ldots$
A. Energy demand and $\mathrm{CO}_{2}$ emissions in the baseline scenario $\ldots \ldots \ldots \ldots \ldots \ldots$
B. The effects of the EC proposal on the EC $\ldots \ldots \ldots \ldots \ldots \ldots \ldots \ldots \ldots \ldots$

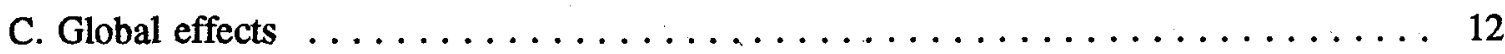

IV. SUMMARY AND CONCLUSIONS $\ldots \ldots \ldots \ldots \ldots \ldots \ldots \ldots \ldots \ldots \ldots \ldots$

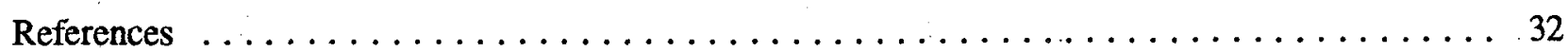





\title{
GLOBAL EFFECTS OF THE EUROPEAN CARBON TAX
}

\author{
Giuseppe Nicoletti and Joaquim Oliveira-Martins ${ }^{1}$
}

\section{INTRODUCTION}

The likelihood of significant global warming by the middle of the next century is mainly linked to increasing world atmospheric concentrations of greenhouse gases (GHGs), of which carbon dioxide $\left(\mathrm{CO}_{2}\right)$ is quantitatively the most significant. Since GHG emissions increase world concentrations independently of the country of origin, climate change is a global phenomenon. The Rio summit set the stage for a global agreement to curb GHG emissions, but it is likely that any concrete steps towards emission abatement in the near future will take the form of unilateral actions, in which single countries or groups of countries will commit themselves to emission abatement policies. These limited agreements may provide incentives to other countries to join the agreed policies through the "example or credibility effect" that unilateral actions could generate. The EC Commission proposal to impose a mixed carbon-cum-energy tax in order to stabilise emissions at their 1990 levels by the year 2000 is the most prominent example to date of such unilateral action.

The aim of this paper is to analyse the implications of the EC proposal from a global perspective, an issue that has attracted considerable attention. Therefore, the paper deals with the effects of this proposal on $\mathrm{CO}_{2}$ emissions and welfare in both the $\mathrm{EC}$ and the rest of the world. The analysis concentrates on three main issues: $i$ ) the effectiveness of the proposed tax measures in terms of curbing EC and global $\mathrm{CO}_{2}$ emissions; ii) the implied costs for the $\mathrm{EC}$ and the other countries/regions of the world; and iii) the implications of the EC proposal for the world distribution of emissions and the competitiveness of the EC economy. In this connection, the relevance of the so-called "carbon leakages" -- i.e. the displacement of polluting activities from countries participating in an emission reduction agreement to countries not concerned by the agreement -- is examined. The paper provides quantitative answers to these issues using simulations with GREEN, the global dynamic applied general equitibrium (AGE) model developed by the OECD Economics Department in order to study the economic effects of policies aimed at reducing emissions of $\mathrm{CO}_{2}$ in the atmosphere. The reader can also refer to Burniaux et al. (1992b) for a broader range of policy issues simulated with GREEN.

Global dynamic AGE models, such as GREEN, are particularly useful tools for analysing the $\mathrm{CO}_{2}$ issue. By modelling the decisions of households and firms, these models are able to capture the economic mechanisms that link in each period of time the available resource base to man-made emissions of $\mathrm{CO}_{2}$, of which around 75 per cent originate from the burning of non-renewable fossil fuels. In addition, dynamic models are able to trace out the evolution of emissions over time as a function of technical progress and the speed of adjustment of the world economy to changes in relative prices. The $\mathrm{CO}_{2}$ issue has important temporal dimensions since i) the increase in GHG concentrations is expected to occur over a long time horizon and involve shifts over time in the regional distribution of emissions; ii) its intensity will depend on the future development of "clean" renewable sources of energy; and iii) adaptation and/or abatement policies are all expected to imply important adjustment costs and shifts in trade patterns. Finally, by explicitly incorporating welfare considerations, AGE models are well-suited to evaluate the regional and global costs of abatement policies over time. 
GREEN has several comparative advantages over other global models designed to analyse the $\mathrm{CO}_{2}$ issue $^{2}$. First, it is the only global model that incorporates full bilateral trade linkages between all regions of the world. The other models either model trade flows inconsistently or rely on the Heckscher-Ohlin assumptions to simplify model structures and data requirements ${ }^{3}$. Second, being mostly based on inputoutput and trade data from individual countries, GREEN allows for a large and flexible regional disaggregation, while at the same time preserving sufficient sectoral detail. These characteristics make GREEN particularly well-suited for the analysis of international competitiveness issues and the simulation of different kinds of regional and global agreements to curb $\mathrm{CO}_{2}$ emissions. Finally, GREEN is also unique among global models in combining full world trade links, regional and sectoral detail and various sources of adjustment costs in production ${ }^{4}$.

However, GREEN also has important limitations for addressing the climate change issue. Some of these are shared by other global models: the only greenhouse gas included is $\mathrm{CO}_{2}$; the benefits of abatement policies (i.e. avoided damages from global warming) are ignored; no distortions in labour supply or the consumption/saving decisions of households are allowed; the international oil market is assumed to be perfectly competitive ${ }^{5}$; sectoral disaggregation is more limited than in national models; perfect labour mobility across sectors is assumed; and no international capital mobility is allowed. Other limitations are more specific to GREEN, such as the assumption that agents have static expectations ${ }^{6}$. Generally, the focus on $\mathrm{CO}_{2}$ and the neglect of benefits will tend to exaggerate the costs of policies aimed at curbing emissions, while the limited sectoral detail and the assumption of perfect labour mobility will tend to underestimate the short-run costs of the policies. On the other hand, the lack of international capital mobility may imply an underestimation of the "carbon leakage" phenomenon. It is difficult to predict how the other limitations of GREEN may affect the simulation results.

The paper is organised as follows. In the next section a brief overview of the GREEN model is provided. The reader is referred to Burniaux et al. (1992a) for a full documentation of the specification, parameterisation and calibration of GREEN. In section III the results from simulating the EC proposal with GREEN are described. First, developments in the composition of energy demand and $\mathrm{CO}_{2}$ emissions in the baseline scenario are described. Second, the EC tax scenario is simulated and the outcomes for energy demand, $\mathrm{CO}_{2}$ emissions and welfare in both the $\mathrm{EC}$ and non-EC countries are analysed. A few concluding remarks summarise the main findings and indicate directions for future research.

\section{OVERVIEW OF THE GREEN MODEL}

The current version of GREEN consists of twelve regional sub-models -- which include four OECD regions and eight non-OECD regions, eleven producer sectors, four consumer sectors and up to fifteen primary factors. All regions are linked together by trade flows concerning each of the produced tradeable goods and bilateral trade flows are separately specified for each pair of regions. The model is simulated over the 1985-2050 period, in five steps of five-year intervals up to 2010 and two further steps of twenty-year intervals. The key dimensions of GREEN are described in Table 1.

\section{A. Producers}

The model highlights the relationships between depletion of fossil fuels, energy production, energy use and $\mathrm{CO}_{2}$ emissions. Therefore, the main focus is on the energy sector and its links to economic activity. Three sources of fossil fuels -- oil, natural gas and coal -- and one source of non-fossil energy, the electricity sector, are distinguished. In addition, non-conventional energy sources -- the so-called "backstop technologies" -. are assumed to become available in the course of the simulation period. 
Backstop technologies are substitutes for gas, oil, coal and conventional electricity generation which are assumed to become commercially available at a fixed price and a fixed date in the future. For each of the three fossil fuels, two alternative backstop technologies are assumed to exist: i) a carbon-based backstop which produces a synthetic fuel with a higher carbon content than the conventional technology; and ii) a carbon-free backstop fuel. The former is a liquid synthetic fuel derived from coal or shale, the latter is a liquid fuel derived, for instance, from biomass. A single carbon-free backstop technology is also available for producing electricity. This backstop represents all non-hydro, non-fission sources of electric power (e.g. nuclear fusion, solar or wind power) ${ }^{7}$.

In each conventional sector, gross output is produced using the four primary energy sources or their backstop alternatives, refined oil products, a fixed factor (land, a fossil fuel or a carbon-free resource), capital, labour and intermediate goods and services. ${ }^{8}$. It is assumed that conventional energy and intermediate inputs can be obtained either from domestic or foreign suppliers. All sectors are assumed to operate with constant returns to scale and share a common production structure, which is depicted in Figures la,b. The quantities of all inputs are optimally chosen by producers in order to minimise production costs given the level of sectoral demand and relative after-tax prices ${ }^{10}$.

An important feature of production in GREEN is the distinction between "old" capital, which was installed in previous periods, and "new" capital, which results from current-period investment. This distinction depends on the presence of adjustment costs, which reflect the economic irreversibility of capital formation when markets for second-hand and new capital goods are incomplete. Costs associated with the dismantling or building of plants are proxied by two assumptions: the production technology is putty/semiputty and the beginning-of-period capital stock is partially mobile across sectors.

\section{B. Consumers}

A single representative consumer is assumed to allocate optimally her/his disposable income among four broad consumer goods -- food and beverages, fuels and power, transport and communication, other goods and services -- and saving. The consumption/saving decision is static: saving is treated as a fifth "good" and its amount is determined simultaneously with the demands for other goods ${ }^{11}$. Saving is assumed to take the form of purchases of investment goods, since no financial intermediation is incorporated in the model. All income generated by economic activity is assumed to be distributed to consumers.

Consumption aggregates differ from the outputs of the eight production sectors and were chosen in order to highlight the principal components of final demand for energy. While the energy intensity of consumer goods is a technical datum, their fuel composition is assumed to be optimally chosen by consumers ${ }^{12}$. Similarly, it is assumed that consumer demand is allocated optimally among domestic and foreign suppliers. The structure of household demand is depicted in Figure 2.

\section{Government}

The government collects carbon and energy taxes, income taxes and indirect taxes on intermediate inputs, outputs and consumer expenditures in order to finance government expenditures ${ }^{13}$. These expenditures partly contribute to final aggregate demand and do not produce any services.

The carbon tax is an excise tax, which is expressed as a fixed absolute amount of US\$ per ton of carbon emitted. The tax is fuel-specific, since it varies directly with the $\mathrm{CO}_{2}$-emission coefficients of oil, coal, natural gas and the carbon-based backstop. It is applied at the level of consumers of primary fuels only, i.e. the tax is applied equally on domestic and imported uses of primary fossil fuels ${ }^{14}$. Thus, for example, refineries are taxed on their use of crude oil, but firms using domestically refined petroleum 
products are not taxed. On the other hand, imports of refined oil products are taxed. The energy tax is also an excise tax, which is expressed as a fixed absolute amount of US\$ per Terajoule. It is a tax on the energy content of energy demand which is applied at the level of consumers of all primary energy sources, including the carbon-free electric energy ${ }^{15}$. Since each primary energy source has a specific carbon content, an energy tax does not equalise the marginal cost of reducing $\mathrm{CO} 2$ emissions across sectors.

Carbon and energy taxes can be either arbitrarily fixed or computed as equilibrium prices associated with a given constraint on total emissions. In the simulations of the present paper, fixed energy and carbon taxes are imposed to yield the mixed carbon-cum-energy tax proposed by the EC.

\section{Foreign trade}

The world trade block is based on a trade sub-model in which each bilateral trade flow is separately specified. The basic assumption is that imports originating in different countries are imperfect substitutes. Therefore, in each country, total import demand for each good is allocated across trading partners according to the relationship between their export prices. This specification of imports -- commonly referred to as the Armington specification -- implies that each country faces downward-sloping demand curves for its exports.

The Armington specification is implemented for all goods except crude oil, which is assumed to be a homogeneous commodity ${ }^{16}$. The world price of oil is determined by marginal costs of production in the energy-exporting LDCs region, given the world demand for oil. At this price, the other regions competitively allocate their demand for oil among domestic supply and imports. Oil-trade flows and market shares result from the balance between domestic demand and supply of oil at given real world prices.

The consistent bilateral world trade links embedded in GREEN make it particularly well-suited to analyse the consequences of carbon taxation and energy market developments for terms of trade and international trade flows. The differentiation of import flows by country of origin makes it possible to quantify the effects of policies on import and export prices and market shares, which determine movements in the terms of trade. The identification of country-specific changes in market shares and export prices is essential in order to evaluate the effectiveness of unilateral emission abatement policies. Changes in international competitiveness implied by these policies may result in displacement of $\mathrm{CO}_{2}$-emitting activities to regions not concerned by the regional emission reduction agreement -- a phenomenon known as "carbon leakage". Moreover, the quantification of terms-of-trade movements is important for the correct evaluation of changes in welfare following carbon taxation policies, since term-of-trade changes can offset or add to the direct efficiency losses resulting from the tax.

\section{E. Closure}

GREEN does not embody any explicit investment behaviour by firms. In each period, the model equates gross investment to net saving. Net saving is the sum of saving by households, the depreciation of capital, the net budget position of the government and foreign capital inflows, which result from the current account balance ${ }^{17}$.

Changes in the government budget induced by carbon and energy tax revenues are compensated by offsetting changes in the marginal income tax rate. Since no labour supply or consumption/saving distortions are included in GREEN, this is equivalent to a lump-sum transfer to households ${ }^{18}$. This compensating mechanism approximates revenue-neutrality, which is considered the appropriate closure to apply to the government sector for long-term simulations. Since government and foreign trade imbalances are exogenous, investment is almost entirely savings driven. 


\section{F. Dynamics}

GREEN is a recursive model. The flow of time is expressed by growth or contraction of baseyear stocks of resources. Agents are assumed to be myopic, basing their decisions on static expectations about prices and quantities ${ }^{19}$. Therefore, the development of the economy over time is characterised by a sequence of period-related, but intertemporally uncoordinated, flow equilibria.

The dynamics in GREEN originate from three sources: depletion of exhaustible resources, capital accumulation and the putty/semi-putty production technology. A resource depletion sub-model is specified for oil and natural gas. The sub-model determines potential supply of these exhaustible resources as opposed to actual output, which is determined by the supply function for the corresponding fixed factors. In each period, potential supply is the maximum amount of the fossil fuel which can be supplied given the initial levels of proven and unproven (so-called "yet-to-find") reserves, the rate of reserve discovery and the rate of extraction. Therefore, potential supply provides an upper bound to actual supply of the fossil fuel. If demand falls short of potential supply, the difference between actual and potential supply is capitalised and added to future reserves of the fossil fuel.

In the aggregate, the basic capital accumulation function equates the current capital stock to the depreciated stock inherited from the previous period plus gross investment. However, at the sectoral level, the accumulation function may be different because industries are allowed to disinvest faster than their (sector-specific) depreciation rates. In this case, sectors contract over time releasing old capital resources that are acquired by expanding sectors as part of their new capital vintage. In each period, the new capital vintage available to expanding industries is equal to the sum of disinvested capital in contracting industries and total saving generated by the economy, consistent with the closure fule of the model. Given the putty/semi-putty structure of production, the proportion of new capital available in each sector is crucial in determining the elasticities of substitution between factors of production.

In simulations, model dynamics are calibrated in each region on exogenous GDP and population growth rates and on given Autonomous Energy Efficiency Improvements (AEEI), which are rates of neutral technical progress in energy use. Under the maintained hypothesis of balanced growth, these exogenous growth rates imply rates of neutral technical progress in the capital/labour/fixed factor bundle ${ }^{20}$. In counter-factual simulations, population growth, AEEI, and technical progress associated with the capital/labour/fixed factor bundle are exogenous and GDP growth rates become endogenous.

\section{G. Welfare measures}

There are two main sources of welfare changes in GREEN when $\mathrm{CO}_{2}$-abatement policies are implemented. First, carbon and/or energy taxation, by affecting the decisions of households and firms, induces distortions in relative prices and changes in disposable income that cause losses of consumer and producer surplus. Second, because these distortions may differ across countries, they translate into termsof-trade effects that change individual countries' real incomes. In many cases, the net effect of these factors on welfare is uncertain a priori and abatement policies can result in either welfare losses or gains. In GREEN, these welfare effects are measured in terms of the Hicksian "equivalent variation", defined to be the amount of income that would have to be taken away from the consumer at pre-policy consumer prices to make him/her as well off as he/she would be at post-policy consumer prices. 


\section{SIMULATING THE COMMISSION'S PROPOSAL}

The joint Energy/Environment Council of EC Ministers decided in October 1990 on a commitment to stabilise emissions in the Community in 2000 at 1990 levels. The EC Commission has recently proposed a comprehensive strategy to the Council to achieve this commitment -- for details, see Commission of the European Communities (1991). An important element of this strategy is the proposal to introduce gradually over time a mixed energy-cum-carbon tax equivalent to $\$ 10$ per barrel of oil in 2000 . The tax would be split 50/50 between an energy component and a carbon content component ${ }^{21}$.

The Commission's proposal envisages exempting certain energy-intensive sectors and sectors heavily exposed to international competition from the tax until the Community's main trading partners take similar measures. However, no decision has yet been taken as to which sectors should be exempt and whether the exemption should be partial or total. For that reason, the tax was applied to all sectors in the GREEN simulation.

\section{A. Energy demand and $\mathrm{CO}_{2}$ emissions in the baseline scenario}

The first step in the exercise involved simulating a plausible "business-as-usual" (BaU) path of emissions, i.e. the path that $\mathrm{CO}_{2}$ emissions would be expected to take in the absence of policy actions to curb their growth ${ }^{22}$. The BaU path then determines the required magnitude of the cut in emissions needed to achieve the Community's stabilisation target. The assumptions about GDP and population growth rates underlying the BaU path are taken from the Energy Modelling Forum 12 (1991) guidelines.

Figure 3 shows the composition of energy demand by the EC over the simulation period in the $\mathrm{BaU}$ scenario. Apart from the steady increase in overall energy demand, three features are noteworthy over the 2010-2050 period: i) the opposite trends of oil and coal consumption; ii) the increasing penetration of the synthetic fuel backstop; and iii) the very limited inroads of the carbon-free electricity backstop. The switch from oil towards coal and the synthetic fuel reflects the steady rise of the (endogenous) real oil price over the simulation period, which is related to the rise in the world energy demand and the depletion of oil reserves in the Energy-exporting LDCs from around $2030 \mathrm{on}$. The rise in the oil price makes it profitable to substitute oil with a cheaper alternative, such as coal, and with costlier alternatives, such as the synthetic fuel and the carbon-free electricity backstop, as soon as these become available in 2010 . However, even by the end of the simulation period, the carbon-free electricity backstop remains a marginal energy source (less than 5 per cent of total energy demand), due to its high relative price.

Figure 4 shows the regional distribution of global carbon emissions in the BaU scenario. Emissions growth over the period to 2050 depends on three main factors: i) projections of GDP growth; ii) movements in real oil prices; and iii) the phasing-in of backstop technologies. The projected deceleration of GDP growth rates tends to slow down emissions growth in the non-OECD countries in the next century. As noted above, the rise in the real oil price encourages substitution towards coal; thereby tending to increase emissions growth. Backstop options affect emissions growth differently, depending upon whether the backstop is "clean" or "dirty". For example, the phasing-in of the carbon-free electricity option in some OECD countries (mainly Japan) contributes to a sharp fall in emissions growth in the OECD area in the first decade of the next century. But after 2010 this effect is more than offset by the growing penetration of the "dirty" synthetic fuel option in OECD countries.

The net outcome of these opposing trends is a stable 2 per cent per annum growth rate of global emissions, yielding almost 19 billion tons of carbon by 2050 . The regional distribution of emissions changes sharply over this period. The OECD countries, which accounted for 49 per cent of global emissions in 1985, only account for 26 per cent in 2050. Similarly, the EC share of global emissions falls 
over the same period from 14.4 per cent to only 6.7 per cent. The rising share of non-OECD emissions reflects above-average GDP growth in several coal-intensive non-OECD countries (such as China and India) and the tendency to switch further towards coal due to rising oil prices. This is exacerbated by the large coal subsidies that keep domestic coal prices well below the world price in China, India, the former Soviet Union and the CEECs.

\section{B. The effects of the EC proposal on the EC}

Figure 5 shows the decomposition of energy demand in the EC following the implementation of the Commission's proposal. The tax gives rise to both energy conservation and energy substitution effects. As expected, overall energy demand is lower than in the $\mathrm{BaU}$ and even declines slightly with respect to 1985 levels. The decline in energy demand by the EC has a depressing effect on the real world oil price (see Figure 6) until 2030, when the supply constraint becomes binding for the Energy-exporting LDCs. Changes in the composition of demand compared with the BaU reflect the carbon-content component of the tax, as well as the different time profile of the oil price. These factors prevent substitution from oil to coal, bringing about a decrease of the coal share relative to BaU, and limit the penetration c: the "dirty" synthetic fuel backstop. At the same time, they imply a larger consumption of the carbon-free :?ectricity backstop (more than 10 per cent of total energy demand by 2050), which becomes increasingly com.. atitive as the gross-of-tax price of oil rises at the end of the simulation period due to the tighter resource consurint in the Energy-exporting LDCs.

These developments in energy demand have an important impact on EC carbon emissions relative to the $\mathrm{BaU}$. Table 2 shows $\mathrm{CO}_{2}$ emissions and their percentage deviations from $\mathrm{BaU}$ levels over the simulation period. As a result of imposing the energy-cum-carbon tax, EC emissions in 2000 are simulated to be 13 per cent below the $\mathrm{BaU}$ level; this is slightly more than would be required to achieve stabilisation at 1990 levels -- emissions in 2000 are 5 per cent lower than in 1990. Maintaining the tax after 2000 continues to exercise a restraining effect on EC emissions: by 2050 , they are almost 40 per cent below the $\mathrm{BaU}$ level. As noted above, the imposition of the tax encourages a switch away from coal and the "dirty" synthetic fuel back-stop towards oil at first and the carbon-free electric back-stop after 2010.

Changes in relative prices implied by the carbon-cum-energy tax have significant impacts at the sectoral level in the EC. Table 3 shows the (cumulated) sectoral output changes relative to baseline for the eight conventional production sectors distinguished in GREEN. Not surprisingly, losses are particularly serious for the coal industry but sizeable losses are also simulated for the gas and refined oil sectors, mainly due to the energy component of the tax. The output loss in the energy-intensive industry is moderate ( -3.5 per cent), even though no tax exemption was simulated for the energy-intensive industry. This can partly be explained by the small share of coal -- the hardest hit energy source -- in total intermediate consumption in this sector in the benchmark year ( 2.2 per cent). The output losses in the other sectors are irrelevant.

The economic costs to the Community, in terms of lower output and welfare, of achieving the commitment to stabilise emissions in 2000 are very small (see Table 4). Real GDP is almost $1 / 2$ of a percentage point below its BaU level in 2010 and the output loss rises slowly to 0.6 per cent by 2050 . These output losses are slightly lower than those reported by a simulation undertaken for the Commission by DRI using its econometric models for eight Member States: this estimated that GDP would be 0.8 per cent lower than baseline after 15 years; they are, however, very close to those reported in Manne and Richels (1992) using the Global 2100 model. The estimated welfare effects are very similar to the GDP losses until 2030. After 2030, the EC suffers a growing terms-of-trade loss -- due to the increase in the price of crude oil -- which aggravates its welfare loss (see Figure 7). By 2050, EC real income is almost $11 / 2$ per cent lower than its BaU level. However, over the whole period, the welfare loss to the EC is only -0.5 per cent (in present values computed assuming a fixed discount rate of $11 / 2$ per cent). 


\section{Global effects}

Although the simulated tax policy appears to overshoot the Commission's stabilisation target slightly, the contribution of this policy to global emissions reduction is negligible: at 18.5 billion tons of carbon in 2050, global emissions are only 2.5 per cent lower than in the BaU.

The global ineffectiveness of the EC policy is mainly due to the declining EC share of global emissions in the $\mathrm{BaU}$, but part of it can be attributed to the phenomenon of "carbon leakages". As the result of the competitiveness loss to European industries after imposing the tax, industries in other regions may become more energy-intensive. To the extent this occurs, $\mathrm{CO}_{2}$ emissions may increase in these other regions, hence the term "carbon leakages". But leakages can be negative as well as positive since income effects resulting from the imposition of the tax may lead to declines in $\mathrm{CO}_{2}$ emissions in regions that do not follow the EC action. The magnitude of the net leakage effect is measured in GREEN in terms of the ratio between the change in emissions outside the $\mathrm{EC}$ and the size of the emissions cut in the EC. The time profile of this ratio and its subdivision among OECD and non-OECD countries are shown in Figure 8. In GREEN, the carbon leakages induced by the EC proposal are moderate: they peak around 11 per cent by 2000 , and then decline thereafter to zero by 2050 .

Positive leakages result from a shift in the comparative advantage of producing energy-intensive goods away from the EC towards the other OECD regions and certain non-OECD regions, notably the former Soviet Union, the CEECs and RoW (Figure 9). The negative leakages are due, in part, to income effects related to the contraction of oil exports from the Energy-exporting LDCs; they also occur in some other regions via inter-fuel substitution. For example, imposing the carbon/energy tax puts downward pressure on the world oil price and this creates less incentives to substitute away from oil in coal-intensive regions, like China.

The extent of the estimated carbon leakages implied by unilateral emission abatement policies depends on two main factors. First, the degree of trade linkages between countries participating in the unilateral agreement and the rest of the world. The decomposition of carbon leakages in the other OECD and non-OECD countries (Figures $9 \mathrm{a}, \mathrm{b}$ ) shows that most of the carbon leakages induced by the EC carboncum-energy tax occur in the other OECD countries. Simulations extending the Commission's tax proposal to all OECD countries yield net carbon leakages that peak at around 3 per cent, due to the relatively small trade flows between the OECD and non-OECD areas. Second, the supply elasticities of fossil fuels are important. The lower these elasticities the higher the carbon leakages, since the decline in the prices of these fuels due to the contraction of demand in carbon-constrained countries will generally lead to an increase in fossil fuel consumption elsewhere. For instance, the profile of net leakages observed in Figure 8 partly reflects the reaction of the real world oil price to the EC restrictions (Figure 6), which is driven by the oil supply elasticity of the Energy-exporting LDCs given the assumption of perfect competition in the world oil market ${ }^{23,24}$.

The EC emission abatement policy has little effect on welfare in other regions of the world (Table 4). The only other region which is affected by the EC tax is the Energy-exporting LDCs. Not surprisingly, this region records lower output and welfare as the imposition of the tax cuts back on EC oil imports. Real output and welfare in the Energy-exporting LDCs is $1 / 4-1 / 2$ of a percentage point below its $\mathrm{BaU}$ level over the period 2000-2050. Its welfare loss reaches a maximum of 1 per cent in 2010 before fading away post-2030 as its terms of trade recover. Its average welfare loss over the whole period (in present values) is -0.6 per cent. 


\section{SUMMARY AND CONCLUSIONS}

In this paper the OECD's GREEN model was used to analyse the effects of the carbon-cum-energy tax proposed by the European Commission on $\mathrm{CO}_{2}$ emissions and welfare in the EC and in the rest of the world. The results of the simulation exercise suggest the following conclusions:

-- The Commission's tax proposal is successful in achieving its target of stabilising EC emissions at 1990 levels by the year 2000. In fact, due to important energy conservation and interfuel substitution effects, the proposed tax policy overshoots this target slightly and implies a continuing emission reduction over the longer run.

-- The contribution of the EC action to global emission reduction is irrelevant, since the EC share of global emissions is projected to decline over time due to the shift in the regional distribution of emissions towards non-OECD countries.

-- The trivial impact of the EC action in curbing world emissions cannot be accounted for by "carbon leakages" to other regions. Net leakages remain moderate throughout the simulation period, partly due to the existence of negative leakages, i.e. reductions in $\mathrm{CO}_{2}$ emissions relative to baseline, in some non-OECD countries.

-- The welfare costs implied by the Commission's tax proposal are small, both in the EC and in other regions of the world.

Given the nature of the simulated policy and the particular assumptions underlying the GREEN model, these conclusions must be qualified in several ways. First, the impact of the Commission's proposal on EC emissions may be overstated, since only the carbon-cum-energy tax was retained in GREEN, while other provisions -- such as sectoral exemptions form the tax -- were ignored. Second, the simulation may have overstated the shift in the distribution of emissions towards non-OECD countries to the extent that existing energy subsidies in many of these countries -- such as China, India, the former Soviet Union and the CEECs -- were assumed to remain unchanged over time. Third, as explained in the text, the degree of carbon leakages may be particularly sensitive to assumptions concerning international capital mobility, the differentiation of goods in international trade and the behaviour of the oil price. Finally, the short-run welfare costs of the tax policy may have been understated given the limited sectoral disaggregation and the assumption of perfect intersectoral labour mobility. 


\begin{tabular}{|c|c|c|c|}
\hline \multicolumn{2}{|c|}{ Producer sectors } & \multicolumn{2}{|c|}{ Consumer sectors } \\
\hline 1) & Agriculture & 1) & Food, beverages and tobacco \\
\hline 2) & Coal mining & 2) & Fuel and power \\
\hline 3) & Crude oil & 3) & Transport and communication \\
\hline 4) & Natural gas & 4) & Other goods and services \\
\hline 5) & Refined oil & & \\
\hline 6) & Electricity, gas and water distribution & & \\
\hline 7) & Energy-intensive industries & & . \\
\hline 8) & Other industries and services & & \\
\hline 9) & Carbon-based back-stop (1) & & \\
\hline 10) & Carbon-free back-stop (2) & & \\
\hline 11) & Carbon-free electric back-stop (3) & & \\
\hline \multicolumn{2}{|c|}{ Regions } & \multicolumn{2}{|c|}{ Primary factors (4) } \\
\hline 1) & United States & 1) & Labour [1] \\
\hline 2) & Japan & 2) & Sector-specific "old capital" [8] \\
\hline 3) & $\mathrm{EC}$ & 3) & "New" capital [1] \\
\hline 4) & Other OECD (5) & 4) & Sector-specific fixed factors for each \\
\hline 5) & Central and Eastern Europe (6) & & fuel [4] \\
\hline 6) & The former Soviet Union & 5) & Land in agriculture [1] \\
\hline 7) & Energy-exporting LDCs (7) & & \\
\hline 8) & China & & \\
\hline 9) & India & & \\
\hline 10) & Dynamic Asian Economies (8) & & \\
\hline 11) & Brazil & & \\
\hline 12) & Rest of the World (ROW) & & \\
\hline
\end{tabular}

1. . Liquid synthetic fuel derived from coal or shale.

2. Carbon-free liquid fuel (e.g. such as derived from biomass).

3. Carbon-free electricity not derived from hydro or nuclear fission sources (e.g. nuclear fusion, solar or wind).

4. Figures in square brackets and bolded represent the number of each primary factor in each regional sub-model.

5. Australia, Canada, New Zealand, EFTA (excluding Switzerland and Iceland) and Turkey.

6. Bulgaria, Czechoslovakia, Hungary, Poland, Romania and Yugoslavia.

7. This grouping includes the OPEC countries as well as other oil-exporting, gas-exporting and coal-exporting countries. For a full listing of the countries, see Table 4 in Burniaux et al. (1992a).

8. Hong Kong, Philippines, Singapore, South Korea, Taiwan and Thailand. 


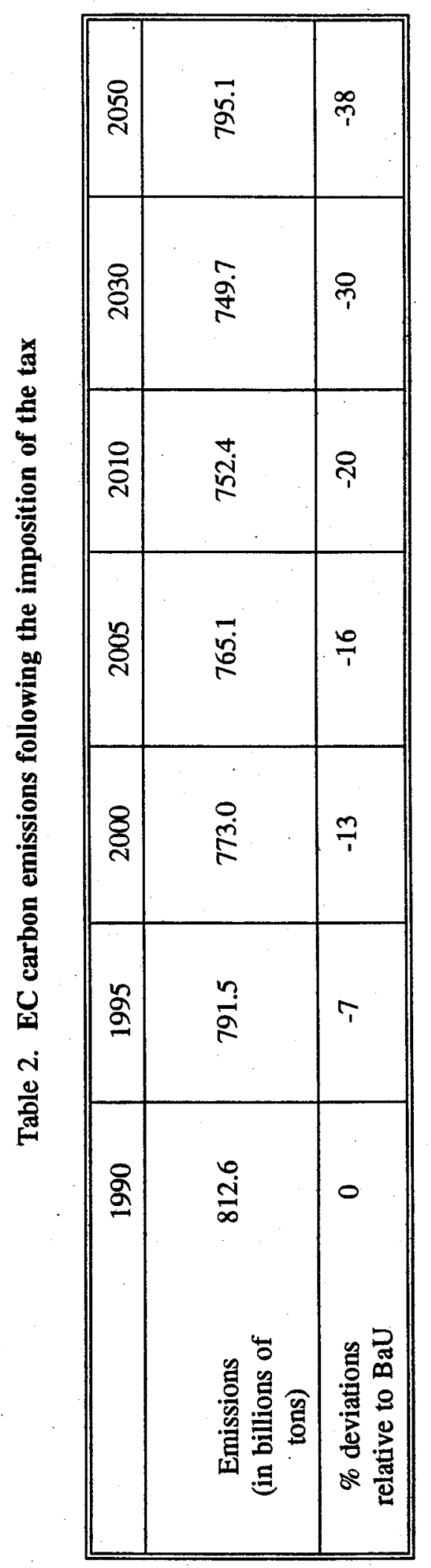




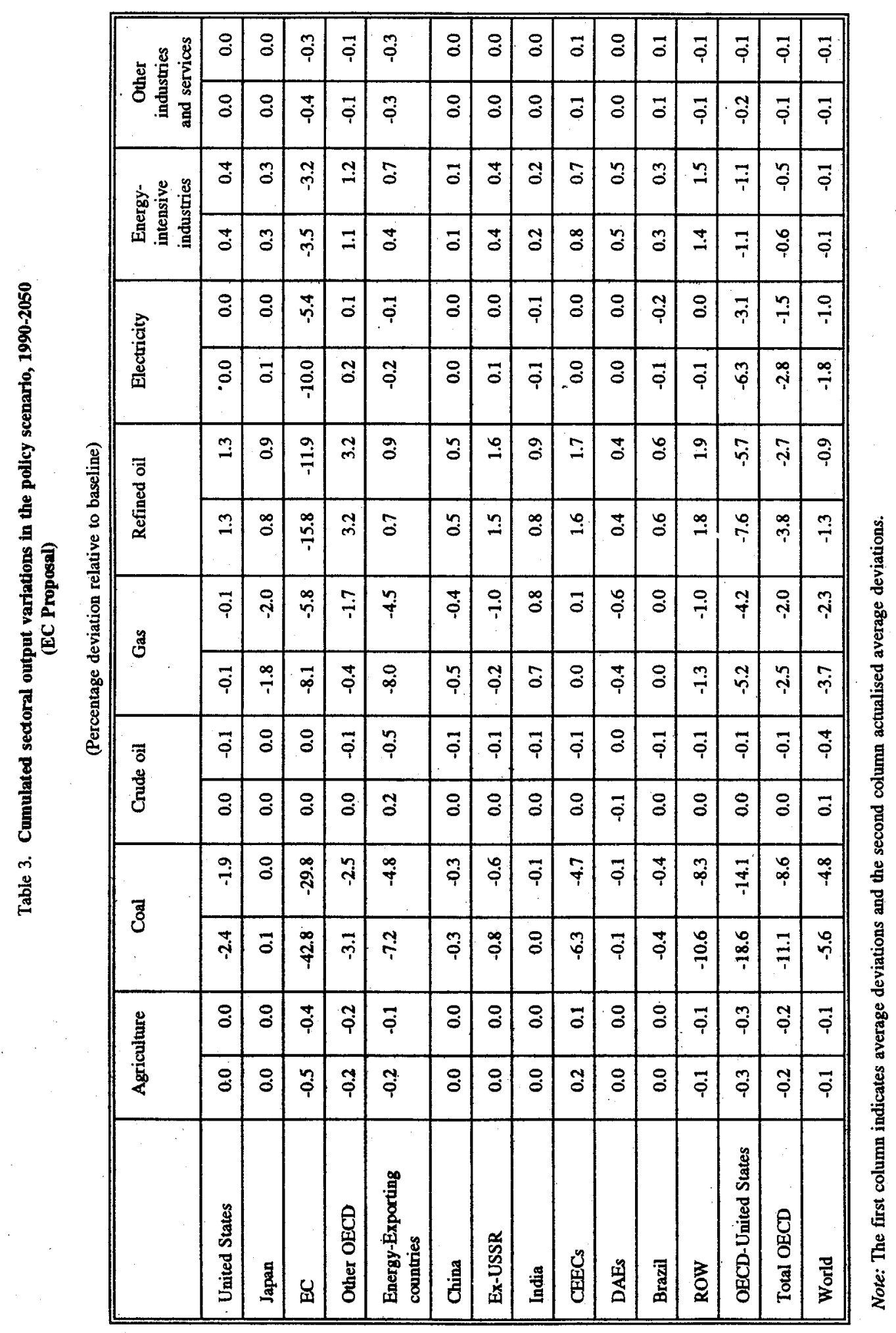


Table 4. Welfare losses: policy scenario (EC Proposal)

\begin{tabular}{|c|c|c|c|c|c|c|}
\hline \multicolumn{7}{|c|}{ GDP losses } \\
\hline \multicolumn{7}{|c|}{ (Percentage deviation relative to $\mathrm{BaU}$ ) } \\
\hline & 1995 & 2000 & 2005 & 2010 & 2030 & 2050 \\
\hline United States & 0.0 & 0.0 & 0.0 & 0.0 & 0.0 & 0.0 \\
\hline Japan & 0.0 & 0.0 & 0.0 & 0.0 & 0.0 & 0.0 \\
\hline EC & -0.1 & -0.2 & -0.3 & -0.4 & -0.6 & -0.6 \\
\hline Other OECD & 0.0 & 0.0 & 0.0 & 0.0 & 0.0 & 0.0 \\
\hline Energy-Exporting LDCs & -0.2 & -0.3 & -0.4 & -0.4 & -0.3 & -0.3 \\
\hline China & 0.0 & 0.0 & 0.0 & 0.0 & 0.0 & 0.0 \\
\hline Ex-USSR & 0.0 & 0.0 & 0.0 & 0.0 & 0.0 & 0.0 \\
\hline India & 0.0 & 0.0 & 0.0 & 0.0 & 0.0 & 0.0 \\
\hline CEECs & 0.0 & 0.1 & 0.1 & 0.1 & 0.1 & 0.1 \\
\hline DAEs & 0.0 & 0.0 & 0.0 & 0.0 & 0.0 & 0.0 \\
\hline Brazil & 0.0 & 0.0 & 0.0 & 0.1 & 0.1 & 0.1 \\
\hline ROW & 0.0 & 0.0 & 0.0 & 0.0 & 0.0 & 0.0 \\
\hline OECD, excluding United States & -0.1 & -0.1 & -0.1 & -0.2 & -0.2 & -0.2 \\
\hline Total OECD & 0.0 & -0.1 & -0.1 & -0.1 & -0.1 & -0.1 \\
\hline World & 0.0 & -0.1 & -0.1 & -0.1 & -0.1 & -0.1 \\
\hline \multicolumn{7}{|c|}{ Household real income lasses (1) } \\
\hline \multicolumn{7}{|c|}{ (Percentage deviation relative to Bau) } \\
\hline & 1995 & 2000 & 2005 & 2010 & 2030 & 2050 \\
\hline United States & 0.0 & 0.0 & 0.0 & 0.0 & 0.0 & 0.0 \\
\hline Japan & 0.0 & 0.1 & 0.1 & 0.1 & 0.0 & 0.0 \\
\hline EC & 0.0 & .0 .2 & .0 .3 & -0.6 & -0.8 & -1.4 \\
\hline Other OECD & 0.0 & -0.1 & -0.1 & -0.1 & -0.1 & 0.0 \\
\hline Energy-Exporting LDCs & -0.4 & -0.8 & $-1: 0$ & -1.1 & -0.4 & -0.1 \\
\hline China & -0.1 & -0.1 & -0.1 & -0.1 & 0.0 & 0.0 \\
\hline Ex-USSR & -0.1 & -0.1 & -0.1 & -0.1 & 0.0 & 0.0 \\
\hline India & 0.0 & 0.0 & 0.0 & 0.0 & 0.0 & 0.0 \\
\hline CEECs & 0.0 & 0.1 & 0.1 & 0.2 & 0.1 & 0.0 \\
\hline DAEs & 0.0 & 0.0 & 0.1 & 0.1 & 0.0 & 0.0 \\
\hline Brazil & 0.1 & 0.2 & 0.2 & 0.3 & 0.1 & 0.1 \\
\hline ROW & -0.1 & -0.2 & -0.2 & -0.1 & -0.1 & 0.0 \\
\hline OECD, excluding United States & 0.0 & -0.1 & -0.1 & -0.3 & -0.4 & -0.5 \\
\hline Total OECD & 0.0 & 0.0 & -0.1 & -0.1 & -0.2 & -0.3 \\
\hline World & -0.1 & -0.1 & .0 .2 & -0.2 & -0.2 & -0.2 \\
\hline
\end{tabular}

1.

Hicksian equivalent variation. 


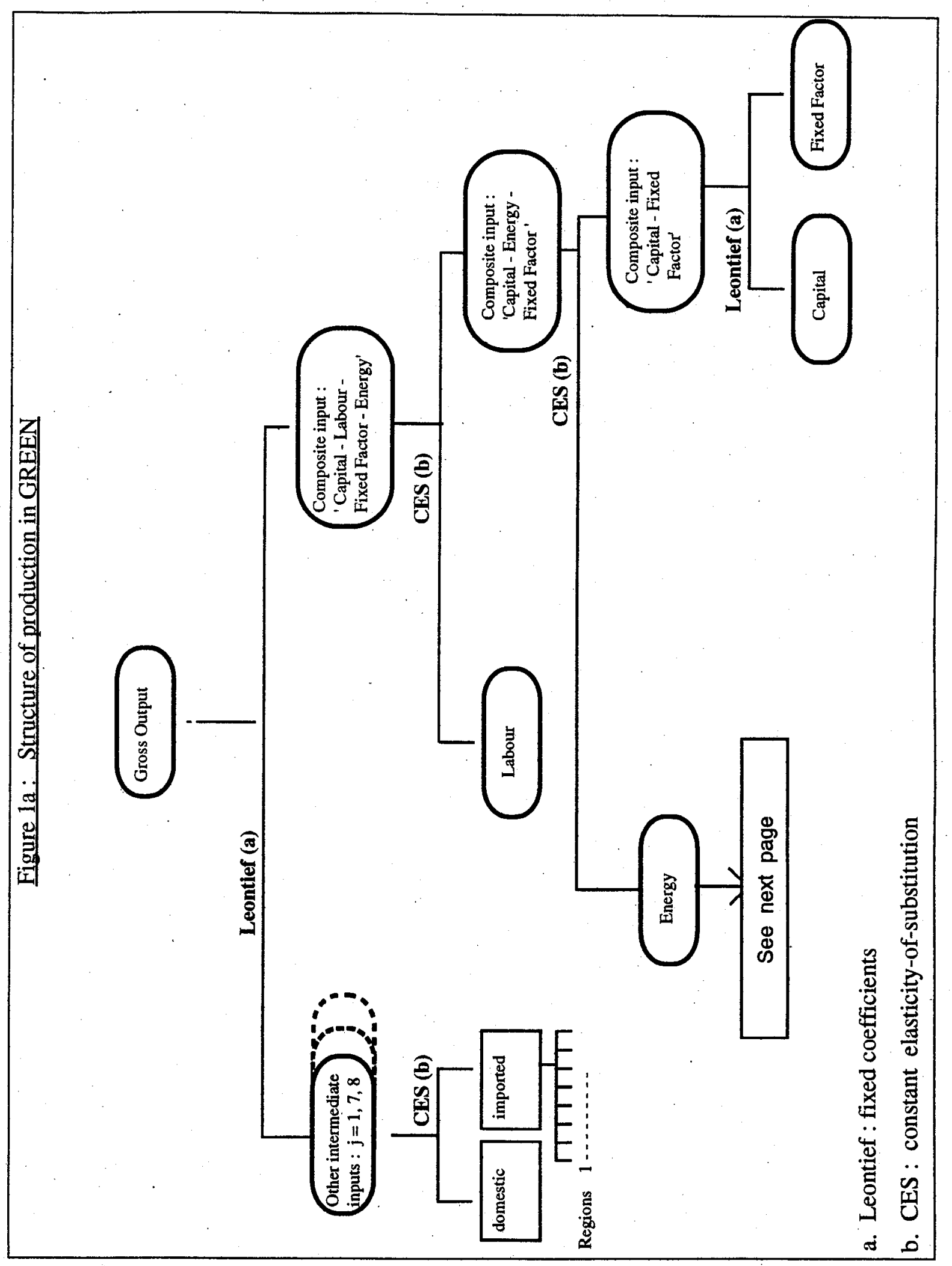




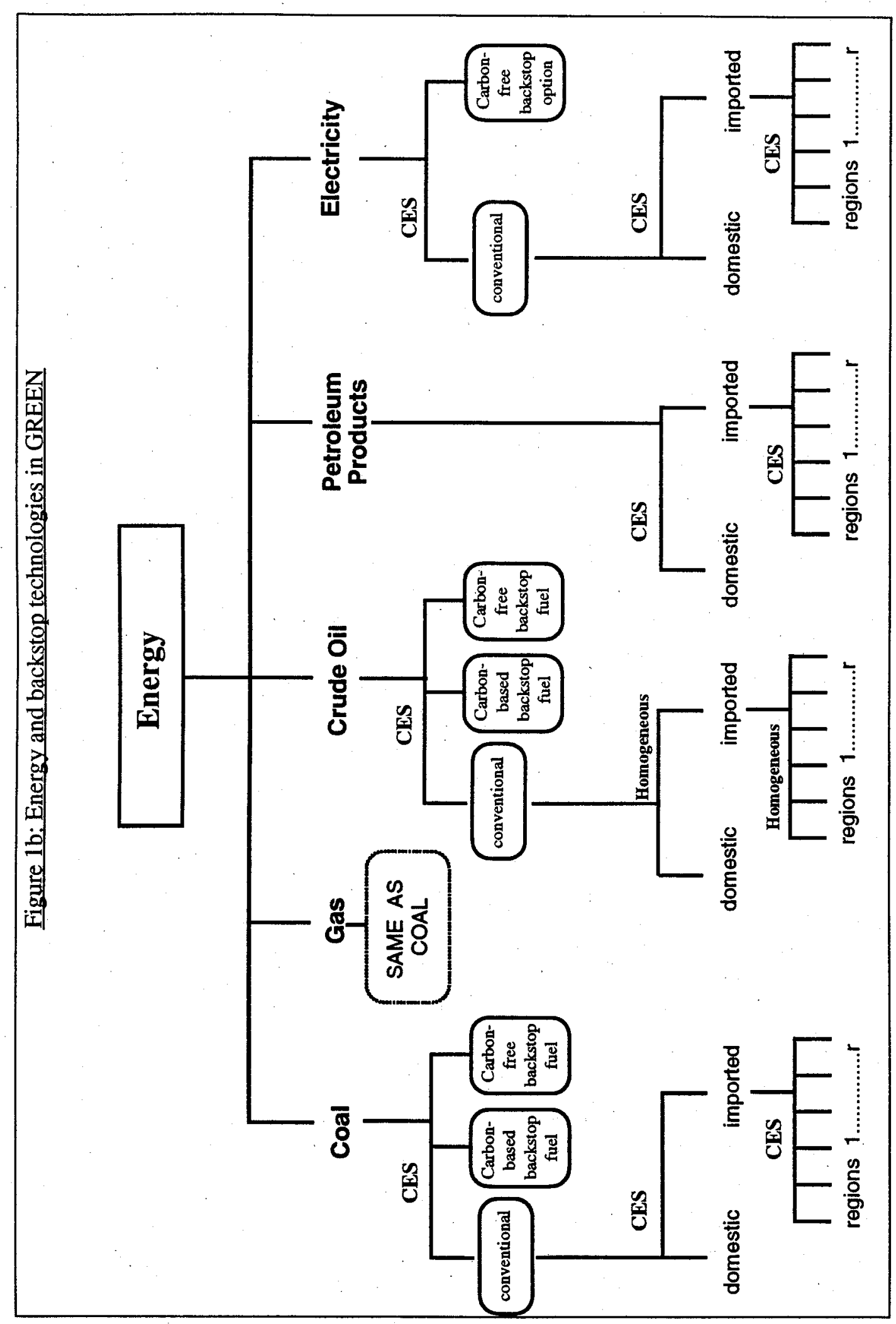




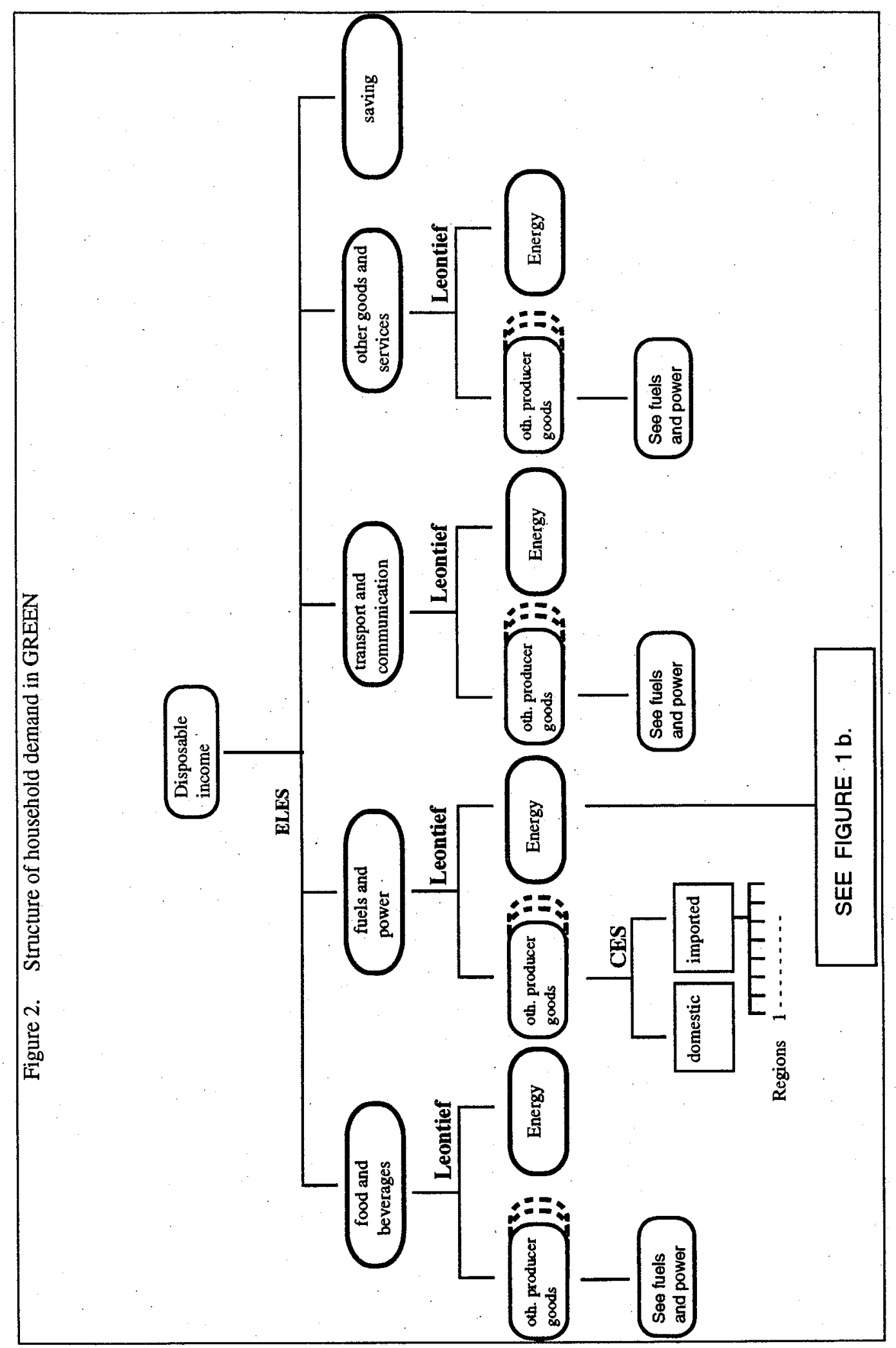




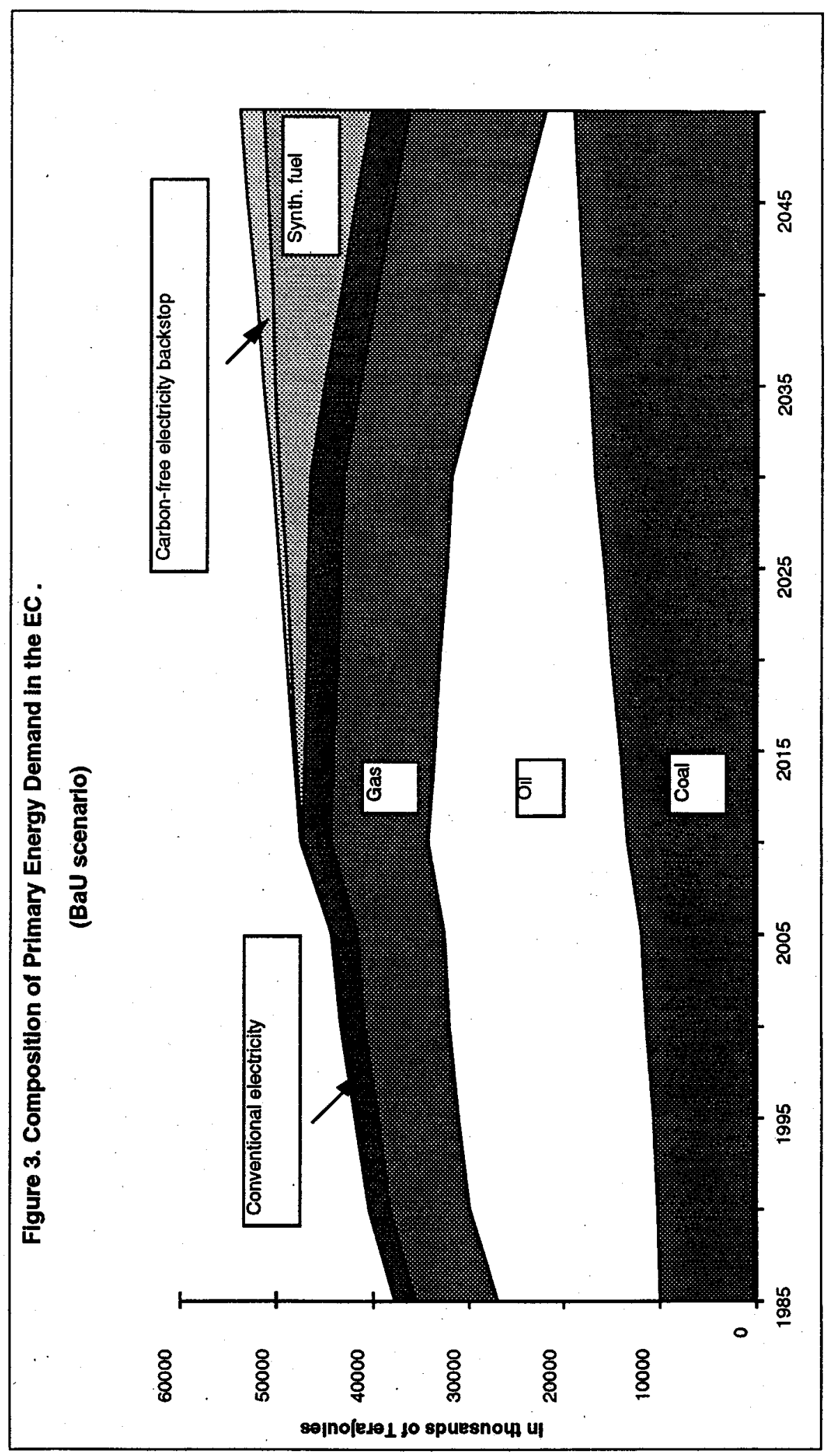




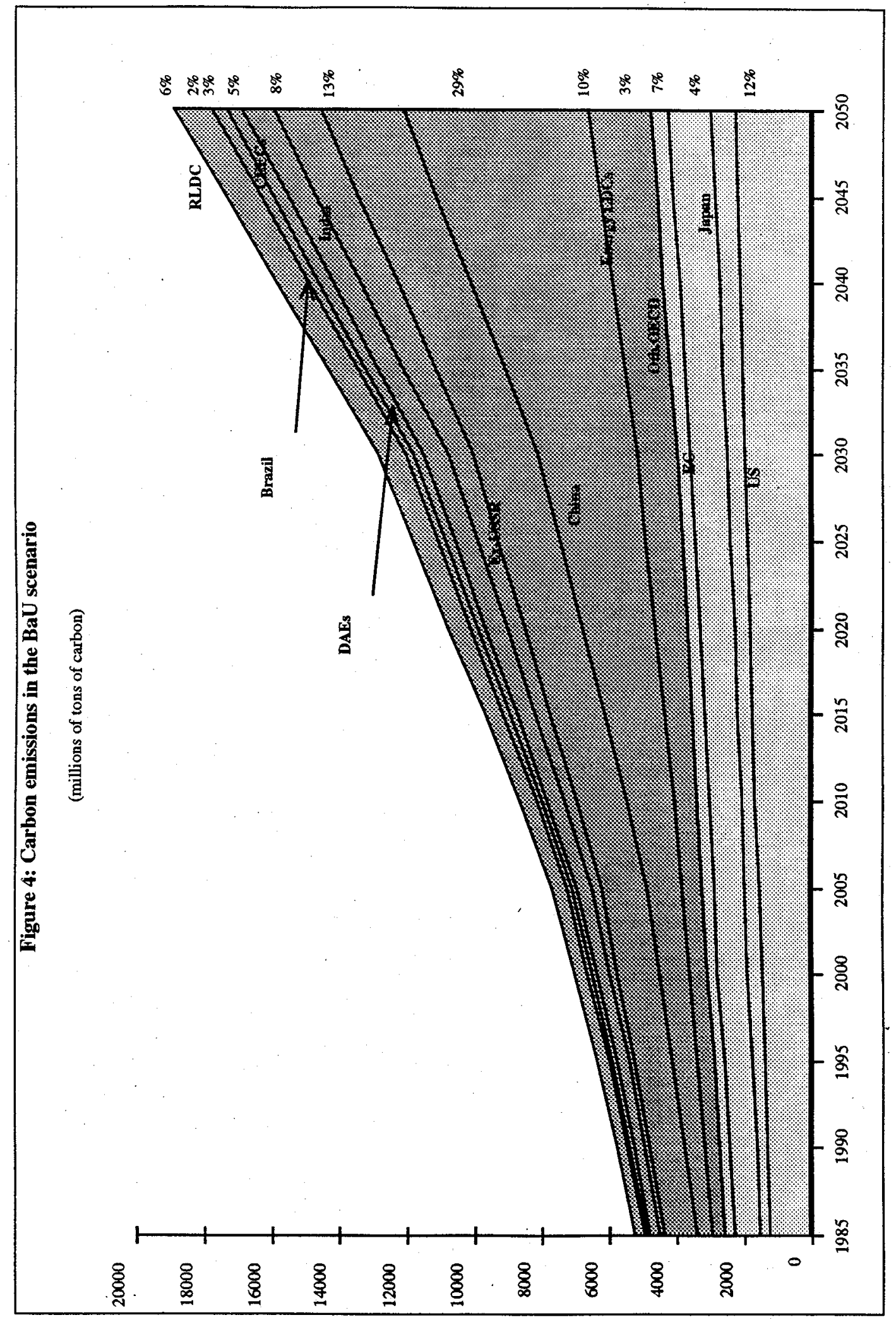




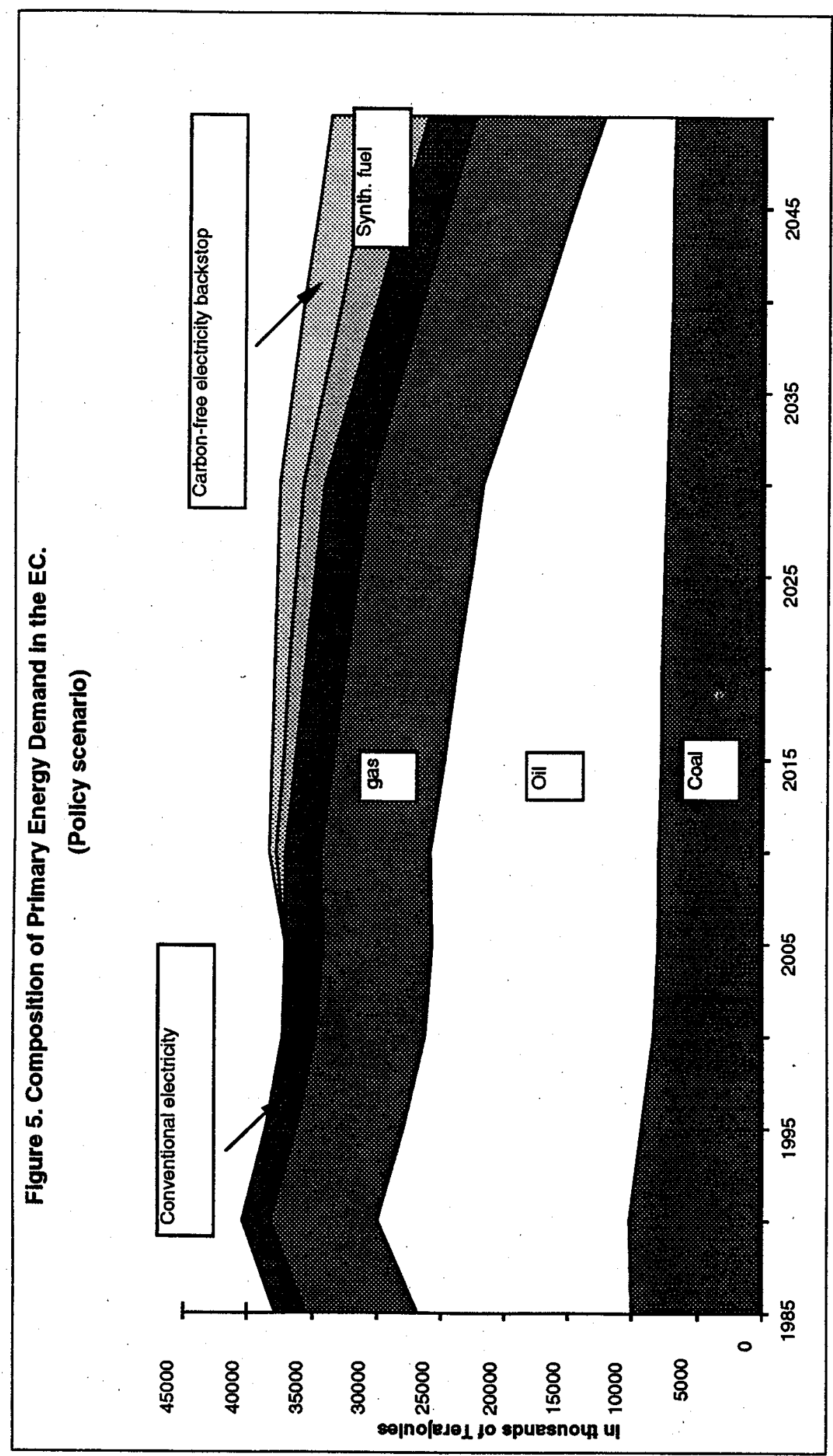




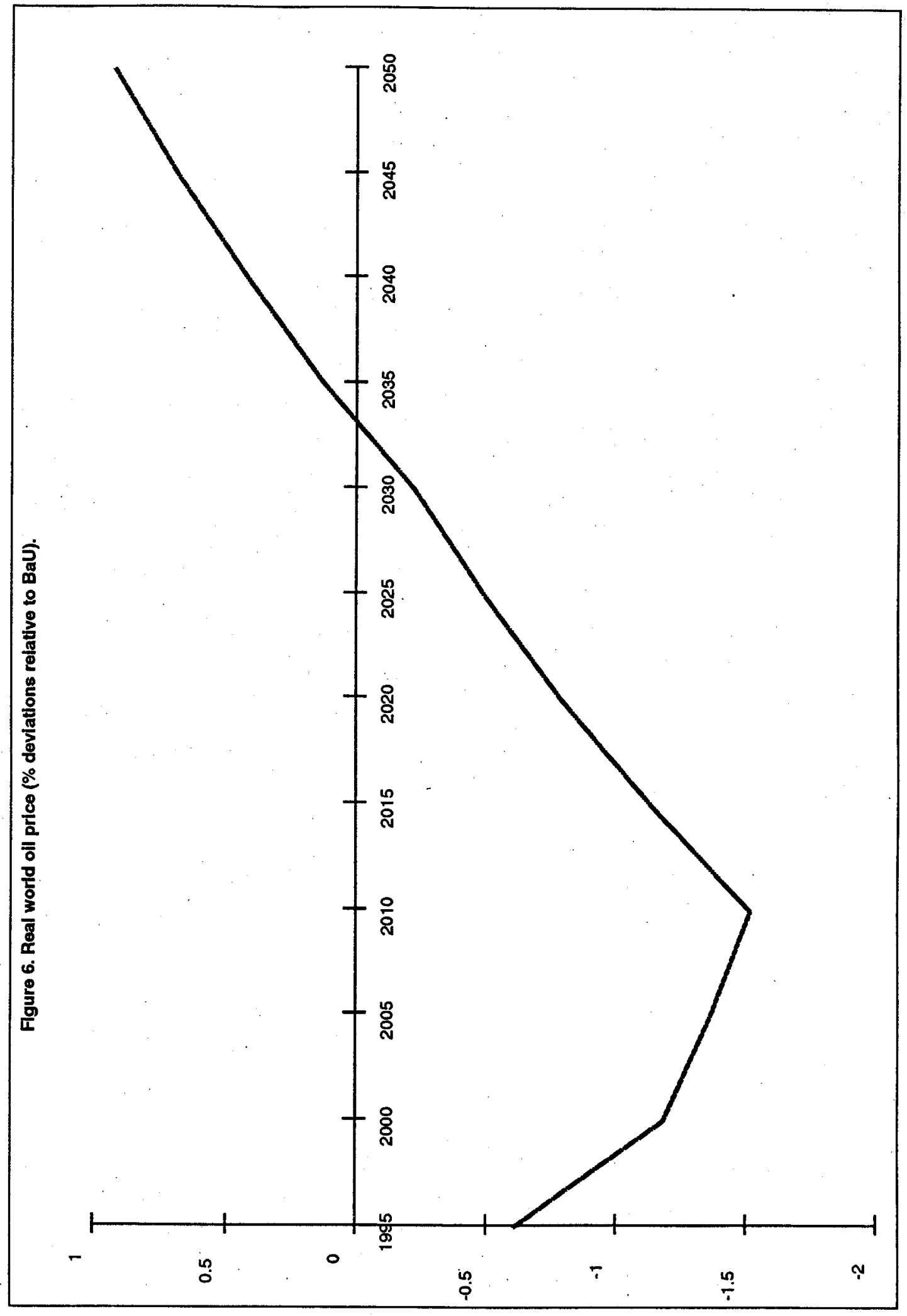




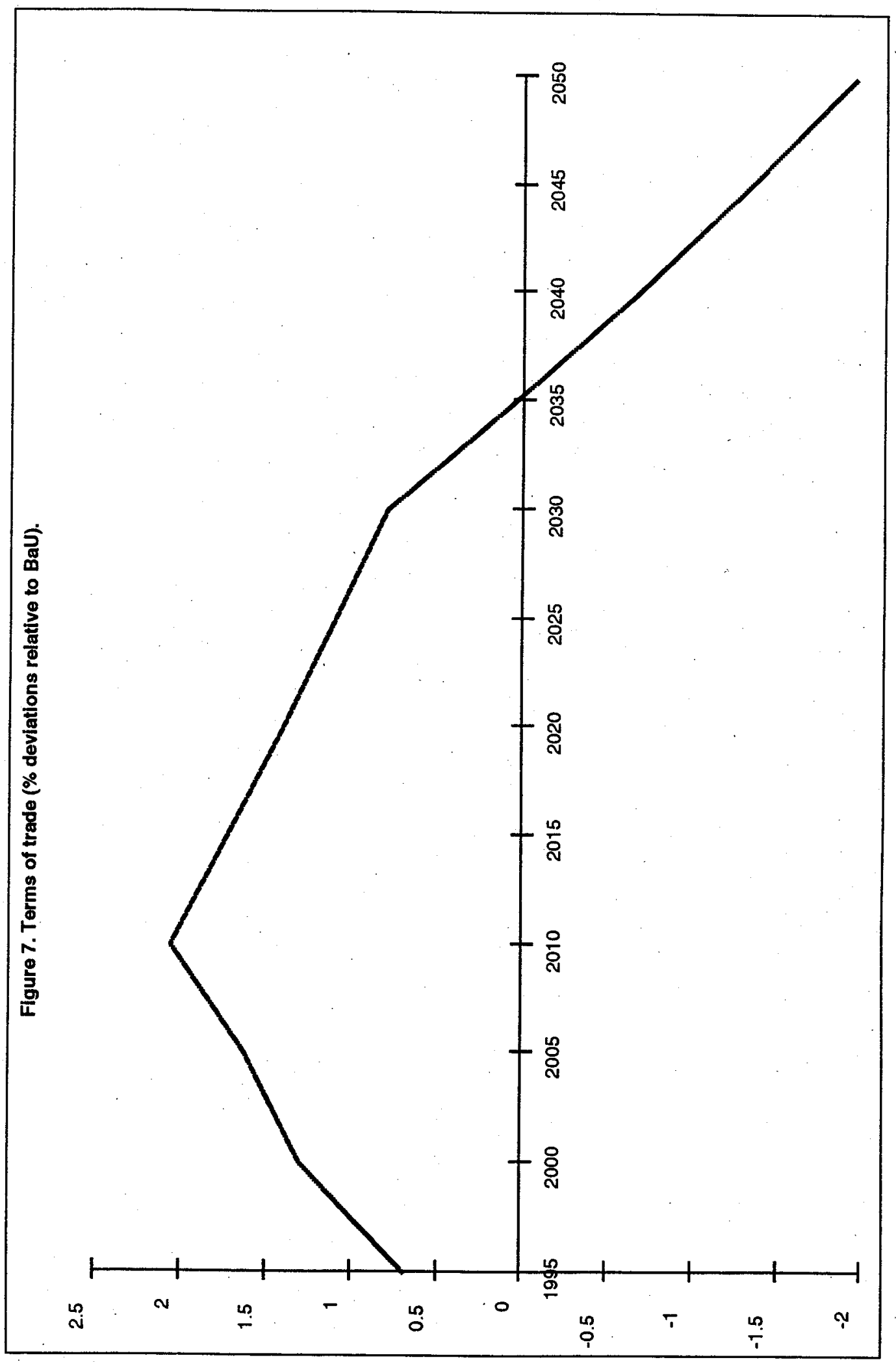




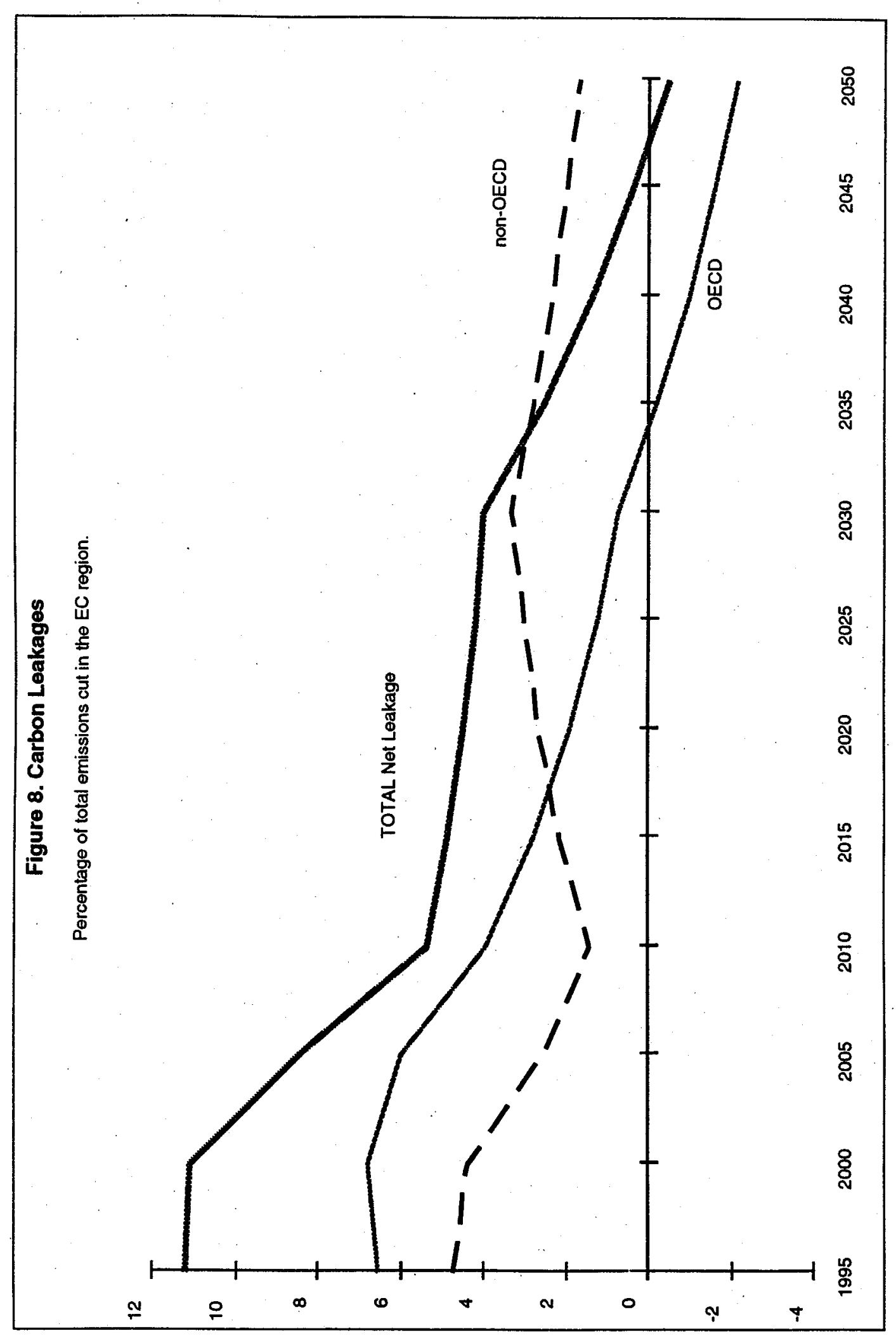

26 


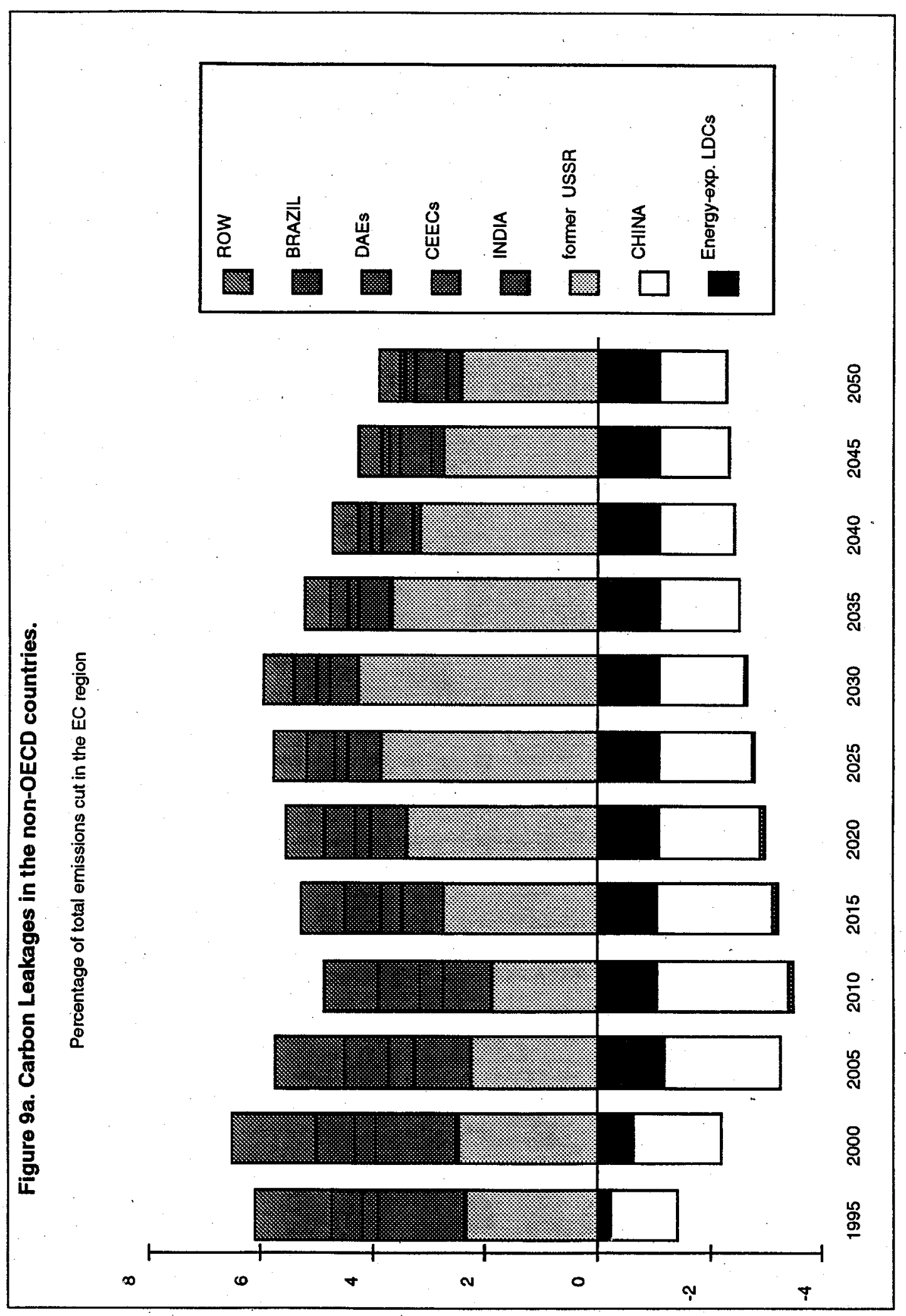




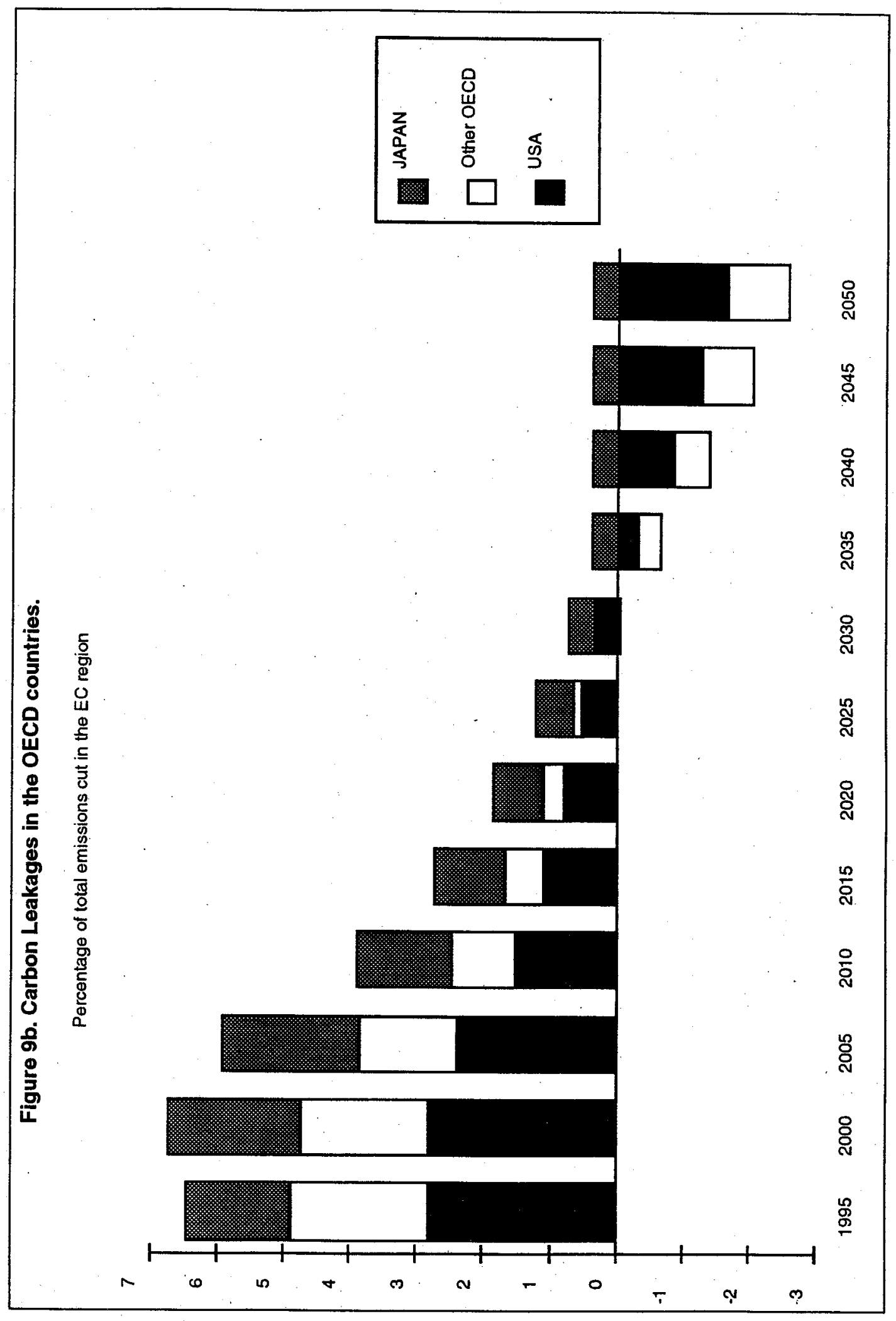




\section{Notes}

1. The authors would like to thank John Martin and Jean-Marc Burniaux for useful suggestions and comments on an earlier draft of this paper. We also want to thank Laurent Moussiegt and Christophe Complainville for very helpful statistical assistance. The views expressed are those of the authors and do not necessarily represent those of the OECD.

2. For a survey of six such global models, see Dean and Hoeller (1992).

3. For instance, the CRTM model of Rutherford (1992) and the model by Whalley and Wigle (1992) model trade flows consistently but adopt the Heckscher-Ohlin specification. On the other hand, the Global 2100 model of Manne and Richels [see Manne (1992)], the Edmonds-Reilly model [see Barns et al. (1992)] and the IEA model [see Vouyoukas (1992)] do not endogenously determine trade flows for all goods.

4. The Global 2100 model of Manne and Richels [see Manne (1992)] incorporates adjustment costs, but the regional detail is limited and trade links are lacking for most sectors. The CRTM model of Rutherford (1992) also incorporates adjustment costs, but the number of regions is smaller than in GREEN and bilateral trade links are lacking. The Edmonds-Reilly model [see Barns et al. (1992)] and the IEA model [see Vouyoukas (1992)] have detailed treatments of adjustment costs in the energy sector, but both use a partial equilibrium framework. The model by Whalley and Wigle (1992) is static.

5. The assumption of perfect competition in the world oil market is shared by the Edmonds-Reilly and Whalley-Wigle models. Other models, such as Global 2100, assume an exogenous world oil price. The CRTM model also assumes an exogenous international oil price, but the price is determined competitively within the RoW region, which includes OPEC.

6. In Global 2100 , households and firms are assumed to take intertemporal decisions based on perfect foresight.

7. Backstop technologies are assumed to become available in all regions in 2010. The carbon-free electricity option is the most expensive of the three backstops. Data on the costs of these backstop options are taken from the guidelines laid down by the Stanford-based Energy Modelling Forum No. 12 exercise on the costs of controlling $\mathrm{CO}_{2}$ emissions.

8. Fossil and non-fossil fixed factors correspond to available resources of coal, natural gas, crude oil and the carbon-free energy source, which includes hydroelectric and nuclear power. These are primary factors, which earn the rents associated with their scarcity.

9. By assumption, backstop products are produced with capital and labour only and are not traded.

10. The production technology combines nested-CES and Leontief production functions (see Figures 1a,b). 
11. Consumer preferences are specified as an "extended linear expenditure system" (ELES). See Lluch (1973).

12: In making this choice, consumers face the same range of conventional and backstop energy products as firms.

13. The government can run deficits (surpluses) but the consequences of the accumulation of net government liabilities (assets) are not taken into account in the model.

14. An alternative strategy would be to levy the tax at the point of production, e.g. at the coal mine or well head. This would have a major impact on the international incidence of the tax. For a good discussion of these issues, see Whalley and Wigle (1991).

15. Since no separate carbon-free electric sector is distinguished in GREEN, the tax is applied at the level of the fixed factor in the electricity sector.

16. Natural gas and coal are assumed to be heterogeneous goods due to transportation costs. These costs are typically much higher for natural gas and coal than for crude oil.

17. Countries can run current account deficits (surpluses), but no account is taken of international income flows associated with changes in the stock of net foreign assets.

18. This means that GREEN cannot quantify the efficiency effects of shifts in the structure of taxation -- an issue that has been analysed by Goulder (1991).

19. Static expectations are typically inconsistent with actual economic outcomes over time. Therefore, future events -- such as pre-announced carbon taxes or depletion of exhaustible resources -- do not have any influence on agents' decisions and market outcomes, until they actually occur. The leading alternative expectational hypothesis is perfect foresight. However, in practice, no software currently exists which is capable of solving a large multi-sector, multi-region dynamic AGE model such as GREEN under the hypothesis of perfect foresight. This technical issue is discussed in Pereira and Shoven (1988).

20. The model assumes a constant capital/abour ratio (in efficiency units) over the simulation period.

21. The tax expressed in US\$ per barrel can be converted into excise taxes in US\$ per Terajoule and US\$ per ton of carbon using the following conversion factors:

1 barrel of oil $=0.00572$ terajoules $=0.11855$ tons of carbon.

Thus, the $\$ 10$ per barrel of oil tax equivalent translates into a tax of $\$ 874.34$ per terajoule and $\$ 42.18$ per ton of carbon.

22. The BaU scenario also assumes that the large observed differences in energy prices across regions in the benchmark (1985) year reflect the marginal social costs of energy production in each region and do not change over time. The implications of this assumption about energy pricing policies are explored in Burniaux et al. (1992b).

23. After 2010 two additional factors come into play. On the one hand, the EC can cut emissions more efficiently by reducing consumption of the synthetic fuel backstop; this implies a smaller decline in the world oil price. On the other hand, the shrinking oil reserves lead to an increase in the real world oil price after 2030 . These factors lead to a progressive decline in net leakages. 
24. Other potentially important factors affecting carbon leakages include the degree of differentiation of goods originating from different countries and the degree of international mobility of capital. Sensitivity analysis raising the elasticities of substitution in international trade showed that net carbon leakages increase as goods become more homogeneous across countries. On the other hand, the assumption in GREEN that capital is non tradeable is likely to imply an underestimation of net carbon leakages, since with capital mobility $\mathrm{CO}_{2}$-emitting industries could be relocated to countries in which the tax is not imposed. 


\section{References}

BARNS, D.W., J.A. EDMONDS and J.M. REILLY (1992), "Use of the Edmonds and Reilly Model to model energy-related greenhouse-gas emissions", OECD Department of Economics and Statistics, Working Papers, No. 113.

BURNIAUX, J.M., J.P. MARTIN, G. NICOLETTI and J. OLIVEIRA MARTINS (1992a), "GREEN -- A multi-sector, multi-region dynamic general equilibrium model for quantifying the costs of curbing $\mathrm{CO}_{2}$ emissions: a technical manual", OECD Economics Department, Working Papers, No. 116.

BURNIAUX, J.M., J.P. MARTIN, G. NICOLETTI and J. OLIVEIRA MARTINS (1992b), "The costs of policies to reduce global emissions of $\mathrm{CO}_{2}$ : evidence from GREEN", OECD Economics Department, Working Papers, No. 115.

Commission of the European Communities (1991), "A community strategy to limit carbon dioxide emissions and to improve energy efficiency", Communication from the Commission to the Council, SEC(91)1744 final, 14 October.

DEAN, A. and P. HOELLER (1992), "Costs of reducing $\mathrm{CO}_{2}$ emissions: evidence from six global models", OECD Economics Department, Working Papers, (forthcoming).

Energy Modelling Forum 12 (1991), "Study design for EMF 12 global climate change: energy sector impacts of greenhouse gas emission control strategies", Energy Modelling Forum, Terman Engineering Center, Stanford University.

GOULDER, L.H. (1991), "Effects of carbon taxes in an economy with prior tax distortions: an intertemporal general equilibrium analysis for the U.S.", mimeo, Stanford University.

LLUCH, C. (1973), "The extended linear expenditure system", European Economic Review, Vol. 4, pp. 21-32.

MANNE, A. (1992), "Global 2100: alternative scenarios for reducing carbon emissions", OECD Economics Department, Working Papers, No. 111.

PEREIRA, A. and SHOVEN, J. (1988), "Survey of dynamic general equilibrium models for tax policy evaluation", Journal of Policy Modelling, 10, pp. 401-436.

RUTHERFORD, T. (1992), "The welfare effects of fossil carbon restrictions: results from a recursively dynamic trade model", OECD Economics Department, Working Papers, No. 112.

VOUYOUKAS, E.L. (1992), "Carbon taxes and $\mathrm{CO}_{2}$ emissions targets: results from the IEA model", OECD Economics Department, Working Papers, No. 114. 
WHALLEY, J. and R. WIGLE (1991), "The international incidence of carbon taxes", in R. Dornbusch and J.M. Poterba (eds.), Global Warming: Economic Policy Responses, Cambridge, Massachusetts, MIT Press.

WHALLEY, J. and R. WIGLE (1992), "Results for the OECD comparative modelling exercise from the Whalley and Wigle model", OECD Economics Department, Working Papers, No. 121. 


\section{ECONOMICS DEPARTMENT}

\section{WORKING PAPERS}

A complete list of Working Papers is available on request.

124. The Chinese Economic Area: Economic Integration Without a Free Trade Agreement (July 1992) Randall Jones, Robert King and Michael Klein

123. New Issues: The OECD's Second Survey of the Macroeconomic Costs of Reducing $\mathrm{CO}_{2}$ Emissions

(July 1992) Peter Hoeller, Andrew Dean and Masahiro Hajafuji

122. Costs of Reducing $\mathrm{CO}_{2}$ Emissions: Evidence from Six Global Models (July 1992) Andrew Dean and Peter Hoeller

121. Results for the OECD Comparative Modelling Project from the WHALLEY-WIGLE Model (July 1992) John Whalley (University of Western Ontario) and Randall Wigle (Wilfrid Laurier University)

120. OECD's Indicators of International Trade and Competitiveness (July.1992) Martine Durand, Jacques Simon and Colin Webb

119. Les indicateurs de compétitivité et de commerce internationaux de l'OCDE (July 1992) Martine Durand, Jacques Simon and Colin Webb

118. The Cost of Reducing $\mathrm{CO}_{2}$ Emissions: A comparison of Carbon Tax Curves with GREEN (July 1992) Joaquim Oliveira-Martins, Jean-Marc Burniaux, John P. Martin and Giuseppe Nicoletti

117. Adjustment under Fixed Exchange Rates : Application to the European Monetary Union (July 1992) A. Steven Englander and Thomas Egebo

116. GREEN: A Multi-sector, Multi-region, Dynamic General Equilibrium Model for Quantifying the Costs of Curbing $\mathrm{CO}_{2}$ Emissions: A Technical Manual

(May 1992) Jean-Marc Burniaux, John P. Martin, Giuseppe Nicoletti and Joaquim Oliveira-Martins

115. The Costs of Reducing $\mathrm{CO}_{2}$ Emissions: Evidence from Green

(May 1992) Jean-Marc Burniaux, John P. Martin, Giuseppe Nicoletti and Joaquim Oliveira-Martins

114. Carbon Taxes and $\mathrm{CO}_{2}$ Emissions Targets: Results from the IEA Model (April 1992) E. Lakis Vouyoukas, IEA

113. Use of the Edmonds-Reilly Model to Model Energy-Related Greenhouse Gas Emissions (April 1992) D.W. Barns, J.A. Edmonds and J.M. Reilly, Pacific Northwest Laboratory, Washington, D.C.

112. The Welfare Effects of Fossil Carbon Restrictions: Results from a Recursively Dynamic Trade Model

(April 1992) Thomas Rutherford, University of Western Ontario 
111. Global 2100: Alternative Scenarios for Reducing Carbon Emissions (April 1992) Alan S. Manne, Stanford University

110. Energy Taxation and Price Distortions in Fossil Fuel Markets: Some Implications for Climate Change Policy

(April 1992) Peter Hoeller and Jonathan Coppel

109. The Information Content of Interest Rate Spreads Across Financial Systems (April 1992) Frank Browne and Warren Tease

108. Is there a future for capital income taxation? (March 1992) Jack M. Mintz

107. A "Credit Crunch"? The Recent Slowdown in Bank Lending and its Implications for Monetary Policy

(March 1992) Paul Francis O’Brien and Frank Browne

106. Energy Prices, Taxes and Carbon Dioxide Emissions (July 1991) Peter Hoeller and Markku Wallin

105. Savings Trends and Measurement Issues

(July 1991) Jeffrey Shafer, Jorgen Elmeskov and Warren Tease

104. GREEN - A Multi-Region Dynamic General Equilibrium Model for Quantifying the Costs of Curbing $\mathrm{CO}_{2}$ Emissions: A Technical Manual (June .1991) J.M. Burniaux, J.P. Martin, G. Nicoletti, J. Oliveira-Martins

103. The Costs of Policies to Reduce Global Emissions of $\mathrm{CO}_{2}$ : Initial Simulation Results with GREEN

(June 1991) J.M. Burniaux, J.P. Martin, G. Nicoletti, J. Oliveira-Martins

102. Patterns of Recoveries for the Major Seven OECD Countries (June 1991) Marco Mira d'Ercole

101. P-Star as an Indicator of Inflationary Pressure (March 1991) Peter Hoeller and Pierre Poret

100. Old Age Income Maintenance (April 1991) Murray Petrie, Peter Sturm

99. The Measurement of Output and Factors of Production for the Business Sector in the 24 OECD Member Countries (March 1991) Mark Keese, Gerard Salou, Pete Richardson

98. Macroeconomic Consequences of Financial Liberalisation: A Summary Report (February 1991) Adrian Blundell-Wignall and Frank Browne 